\title{
As Many As Six Impossible Things Before Breakfast
}

\author{
Don Herzog†
}

That there are fashions in the academy is no surprise, but we might spend more time than we do contemplating the possibility that our latest infatuations, like some clothing styles, are neither new nor particularly attractive. Here I want to explore just that possibility in examining the polemic against liberatism offered by that hardy if looseknit troupe of scholars marching under the banner of critical legal studies.

My real interest isn't in the novelty of that polemic, about which I will say only a few words. Despite some very chic borrowings from the likes of Derrida and Adorno, the CLS polemic is remarkably old. Indeed, this critique of liberalism is as old as hiberatism itself. Roberto Unger's Knowledge and Politics has impressed many im legal circles as a strikingly original work, but for those of us trained in pohtical theory it's quite familiar, a quaint pastiche of Hegehan formulas about the Riddles of Modernity and sentiments reminiscent of nothing so inuch as de Maistre's reactionary-theocratic indictment of the French Revolution. But novelty isn't the real issue here. After all, if the CLS critique of liberalisin is right, it doesn't matter if it's old.

So my real interest is im the inerits of the polemic, and I will offer no further comments on its genealogy. Liberalisin has ennerged, however inplausibly, as a creaky old doctrine that inspires ouly groans and boredoin on the left. Individual rights, equal opportunity, equality under the law: such familiar liberal categories elicit instant recognition but also political and intellectual fatigue. They seem to many to be trite or worse

$\dagger$ Assistant Professor of Political Science, University of Michigan. A.B. 1978, Cornell University; M.A. 1980, Ph.D. 1982, Harvard University. The title derives from Through the Looking-Glass:

"Let's consider your age to begin with-how old are you?"

"I'm seven and a half, exactly."

"You needn't say 'exactly'" the Queen remarked. "I can believe it without that. Now I'll give you something to believe. I'm just one hundred and one, five months and a day." "I can't believe that!" said Alice.

"Can't you?" the Queen said in a pitying tone. "Try again, draw a long breath and shut your eyes."

Alice laughed. "There's no use trying," she said, "one can't believe impossible things."

"I daresay you haven't had much practice," said the Queen.

"When I was your age, I always did it for half-an-hour a day. Why sometimes I've believed as many as six impossible things before breakfast."

L. Carroll, Through the Looking-Glass (1871). 
yet nefarious coverups for the continuing failure of allegedly liberal societies to deal with poverty and racism, exploitation and sexism, neocolonialism and the all too well orchestrated government suppression of radical politics. Such a train of thought, I conjecture, frequently motivates crusades against liberalism. And such crusades are only redoubled by encountering self-avowed liberals who are complacent, even smug, in downplaying or denying our social and political problems.

There is then a political backdrop to academic debates about liberalism (in case anyone missed this favorite CLS insight). But it's perfectly coherent to agree that we face severe probleins and at the same time to embrace liberalism. Indeed, one might think that liberalisin provides just the right resources for criticizing our practices and suggesting changes. (If you disapprove of our politics, and our dominant self-understanding is that we're liberals, you have two choices. You can reject liberalism, making it easy for people to ignore your challenge, or you can offer an account of liberalism that's more critical of our politics. That move seems not only politically more compelling, but intellectually rightthougli as I hope to suggest in this Essay, that contrast is easily overdrawn in political theory.) To take that possibility seriously, we need to recapture some of the content and surprise of liberalisin.

I realize full well that taking on CLS as a whole may seem misguided, largely because the movement is, perhaps commendably, not particularly unified. There's a long way from Karl Klare's work on labor law to Peter Gabel's renditions of everyday life, even if both are more or less Marxist. There's a long way too from Mark Tuslinet's radical skepticism about interpretation to Duncan Kennedy's playful flirtations with what I read as a romantic anarchism, even if neitler has much of anything to do with Marxism. However noteworthy these differences are in other contexts, thougl, they make no difference liere. For if there is anything that CLS writers sliare, it's a pronounced antipathy to liberalism.

\section{A New Fundamental Contradiction}

Duncan Kennedy suggested some time ago tliat social life is based on a fundamental contradiction: we need other people to be free, but they can harin us. ${ }^{1}$ The formulation invites snide rejoinders: we need water to survive, but it can drown us. ${ }^{2}$ Regardless, it has been echoed sympatlietically by many otlier CLS writers as a profound insight into human affairs. ${ }^{3}$

1. Kennedy, The Structure of Blackstone's Commentaries, 28 Buffalo L. Rev. 205, 211-13

2. I owe the rejoinder to Laurie Solon, who offered it not as a snide rejoinder, but thinking she hadn't understood the contradiction.

3. A casual sample of echoes: Feinman, Critical Approaches to Contract Law, 30 UCLA L. 
Kennedy, though, has now renounced the contradiction, complaining that it's been reified: "[I]t must be utterly extirpated and rooted out of our movement as an example of mcorrect thought." ${ }^{4}$ No doubt he'd be the first to concede that he has no property rights in it, so others are free to go on using it without his permission. Still, I'd agree that the contradiction's time has come and gone for CLS. It no longer has any shock value, even if it once did.

CLS, though, thrives on contradictions, the more fundamental the merrier. So I'd like to propose a new contradiction, this one located not in the structure of human reahty but in CLS work. To put it in its inost coinpressed form: CLS authors read legal doctrine politically, but they read liberal doctrine apohitically. It's not surprising that as a result liberalism looks inanifestly inadequate to deal with any of the puzzles they generate in their assaults on legal doctrine.

I have been paraphrasing Clausewitz for soine time, and imsisting that law is the continuation of politics by other means. So I was happy to find CLS writers hammering away at the same theme. "Law is simply politics by other ineans;" "Law is simply politics dressed in different garb;"6 and, nost stridently, "LAW IS POLITICS, pure and simple."7 That last formulation confirms a doubt I've had about CLS work, that it focuses too much on the pohtical aspects of law, and doesn't seriously enough consider the implications of "by other means." But if in fact it's common in law schools these days to treat law as nonpolitical, the CLS sloganeering and the work it gives rise to are well-placed correctives.

When CLS authors turn their attention to liberalism, though, they forget about politics. The subjectivity of value; appeals to individualism and egoism; the naturalness or objectivity of social relationships, and the appeal of private property and capitalism; the najestic coherence and autonoiny of law: all are treated by CLS authors as clains about metaphysics, episteinology, the structure of the self, ethics-as anything but political claims. It's as though liberals began with various abstruse philosophical premises and from them deduced liberal politics. This reading of liberalism is naive and misleading. Every one of these themes in liberal thought, I will argue, has an overtly political function.

That this possibility has been utterly neglected by scholars who

REv. 829, 847 (1983); Frug, The Ideology of Bureaucracy in American Law, 97 HaRv. L. REV. 1277, 1290 (1984); Gordon, New Developments in Legal Theory, in THE Politics of LAw 281, 288 (D. Kairys ed. 1982).

4. Gabel \& Kennedy, Roll Over Beethoven, 36 StaN. L. REv. 1, 18 (1984).

5. Kairys, Legal Reasoning, in The Politics of LAw, supra note 3, at 11, 17.

6. Hutchinson \& Monahan, Law, Politics, and the Critical Legal Scholars: The Unfolding Drama of American Legal Thought, 36 STAN. L. REv. 199, 206 (1984).

7. Schlegel, Notcs Toward an Intimate, Opinionated, and Affectionate History of the Conference on Critical Legal Studies, 36 STAN. L. REV. 391, 411 (1984). 
pride themselves on finding politics lurking everywhere is instructive. It tells us something about an all too common approach to the liberal tradition, an approach that flattens a rich tradition. I don't teach in a law school, and I haven't taken classes in a law school, so I'm not in the best position to say what law professors who call themselves liberals defend. (Still, I don't mean to present myself-Durkheim forbid!-as an isolated individual, essentially unconnected to law schools. My wife is a lawyer, and friends teach in law schools, so I have some unhappy glimmerings of what goes on there.) But if the CLS indictment has any audience, and isn't just an attack on an elaborately constructed straw man, what passes for liberahism in law schools is pretty sorry stuff, a sham of a mockery of a farce. ${ }^{8}$ What follows, then, may not be just a critique of CLS. It may also be an invitation to self-styled liberal legal academics to think more seriously about liberalism.

\section{The SUBJeCtivity OF VAlUES}

Values, liberals have suggested, are all subjective, mere personal preferences, arbitrary, whimsical. It's a mistake to think they are part of the fabric of the universe, to think that objectively any human life plan is better than any other. Instead the universe is ethically mute; ends are posited by individuals. As Hobbes puts it, in a typically memorable formulation,

whatsoever is the object of any mans Appetite or Desire; that is it, which he for his part calleth Good: And the object of his Hate, and Aversion, Evill; And of his Contempt, Vile, and Inconsiderable. For these words of Good, Evill, and Contemptible, are ever used with relation to the person that useth them: There being nothing simply and absolutely so; nor any common Rule of Good and Evill, to be taken from the nature of the objects themselves .... 9

What should we make of this talk?

Unger takes it all at face value, and makes the subjectivity of values one of the chief props of what he calls the prison house of liberal thought, a set of pernicious assumptions that we can escape only through the heroic activity of total critique. Here, he argues, is one of the chief antinomies of liberalism: all values are subjective, but to maintain order we need authoritative public rules that bind everyone. Liberals need to hold both views, but as a unit they're manifestly incoherent. Because liberals can't appeal to any objective values, rules that don't appeal to self-inter-

8. Cf. Schwartz, With Gun and Camera Through Darkest CLS-Land, 36 STAN. L. REv. 413, 446-47 (1984) (suggesting that in fact liberals in law schools do not hold the views attributed to them by CLS writers).

9. T. HobBes, LeviathaN 120 (C.B. MacPherson ed. 1981) (1651). 
est can bind only by coercion. ${ }^{10}$ Kennedy insists that the subjectivity of values is an essential prop in understanding the appeal of legal formality, that casting values as subjective allows us to cast facts as objective, and so makes legal decisionmaking look far less problematic than it really is. Legal rules, in the formalist understanding, focus only on objective facts of the matter, and so can be apphied inechanically to produce certain, predictable results. ${ }^{11}$

Since Hobbes is the relevant villain here, we might well begin by asking what role the subjectivity of values plays in Leviathan. It can't be an epistemological thesis which Hobbes beheves is simply true; if it were, we would have to take Hobbes's own recommendations as mere autobiographical confessions of preference. Since that would make the book pointless, we need another reading. What does Hobbes actually do with claims about subjectivity?

The answer, simply put, is that he enthusiastically debunks offensive pohitical claims. Notoriously, Hobbes scotches a debate stretching back to Aristotle on tyranny. Tyrants, Hobbes insists, are merely monarchs misliked. It's a mistake to look for any objective features in the world that deinarcate thein from legitimate monarchs.

The point of bursting this particular bubble should be obvious. Claims that kings are really tyrants are pohitically explosive, and those clains were pressed endlessly against Charles I in England. Hobbes is acutely aware that overheated pohtical rhetoric inoves political actors, that even muttered imprecations about tyranny destabilize sovereign power. He needs then to silence such charges. One way of doing so, hardly the ouly strategy adopted in his book, is to insist blithely that it's all subjective. If my neighbor tells me that Charles is a tyrant, I may be inclined to join the New Model Army and fight against him. If, however, a Hobbesian imp informs me that my neighbor has said only that he dislikes Charles, I may just shrug and get back to my chores. Similarly, if my neighbor brandishes Milton's Tenure of Kings and Magistrates and tells ine that the law of nature hicenses killing tyrants, the imp will debunk the claim, telling me that once again I have been given only a curiously puffed-up version of a personal preference.

Subjectivism thus functions as a political sedative, robbing evaluative clains of their inflammatory edge. This of course immediately suggests another CLS-style critique: "Aha! So on your account the political upshot of subjectivisin is to increase the masses' political lethargy." Quite so; but before redoubling the critique of liberalisin, we should recall that political contexts vary. In the midst of a heated religious civil

10. See R. Unger, KNowledge ANd Politics 63-103 (1975).

11. See Kennedy, Legal Formality, 2 J. LEGAI STUD. 351, 363-64 (1973). 
war, it's not irresponsible or manipulative to want to smooth over some political conflicts. It's no accident that in later contexts, contexts marked more by complacency and even sleepiness, liberals dropped claims about the subjectivity of values and turned to stirring rhetoric about natural rights and the rest.

One postscript: hiberals often insist too on reason as a great value in human affairs. Suddenly reason is transformed from a purely instrumental capacity to realize arbitrarily posited ends into a transcendent value of some sort. Once again, some will be inclined to catch up liberals in another wretchedly confused contradiction. (I haven't come across this move in the CLS literature, but maybe it's just a matter of time.) To some extent, one could save the tradition by noting that there are two different strands of liberalism, one focusing on the passions, the other on reason. ${ }^{12}$ But in fact there are imdividual hiberals who make both moves. Jolin Locke, for mstance, embraces a subjectivist account of good in his Essay Concerning Human Understanding, but routinely invokes reason as a guide in his political writings. What does this mean politically?

Talk about reason in liberal theory is typically aimed at religious understandings and practices. Locke for instance invokes reason in an attempt to capture those sympathetic to Thomist politics, or more topically to Hooker. Through the Enlightenment, though, the political significance of bowing to reason is transparent-and enthusiastically abusive. Enlightenment authors such as Helvetius and Holbach use reason as a club not because they have a naive view of the powers of human cognition in social life, but to bash the Roman Catholic Church. When a liberal author insists on the place of reason in human affairs, place a bet that lurking nearby is a priest who needs to be discredited. Or, to put the point another way, don't marvel at the failure of liberals to take note of the deep place of mystification and passion in human affairs (more on that in a bit); remember instead the awesome hierarchical power that the Church used its miracles and inysteries to maintain.

\section{INDIVIDUALISM AND EGOISM}

Another common charge against liberalism, one echoed frequently in the CLS hiterature, is that its conception of the self is crude. This charge is in fact a cluster of connected complaints: Liberals try vainly to reduce social totalities to claims about individuals; they fail to realize that selves are social products; and they assume that everyone is out to realize her own self-interest. Liberals thus preclude the very possibility of striving for communal values. Comınunity looks unintelligible from a liberal point of view, it is said, but that doesn't show there's anything

12. See, e.g., A. GutmanN, Liberal Equality 18-47 (1980). 
wrong with community; to the contrary. CLS authors have put some new stylistic twists on this-neither Durkheim nor Michael Sandel would ever talk about intersubjective zap-but the story is familiar enough.

Again, we need not read liberal claims as a series of points about the methodology of the social sciences, or the constituent mechanisms of human behavior. Instead we can read them as political points. And if we do, they become enormously attractive. Let me consider each in turn.

Why cast people as solitary individuals mstead of members of groups? What is the strategic function of ignoring and even denying the obvious fact that personal identity is constituted partly by group memberships? Recall that groups have pressed extraordinary demands on their members. I'm averse to chiding CLS by conjuring up the atrocities of Stalinisin, since I do think that no CLS author I've read has any sympatliies witlı such a politics. (In a lucid article, Ed Sparer argues that CLS sliould not abandon riglits theory, lest they inadvertently usher in such a politics. ${ }^{13}$ This is exactly tlie riglit political move: Belief in huinan rights isn't like behef in gliosts; ${ }^{14}$ rather it's defensible insofar as the social practices framed by rights are tlieinselves defensible.) But the stereotypical story of the cell member dutifully taking orders from on high miglit stand here as a model of the extraordinary deinands imposed by groups. Puritan saints, revolutionary workers, committed nationalists: All liave been willing to demand life itself.

There may be times and places where the deinand is justified. But insistence on the primacy of the group may serve to mystify the issues at stake. Hobbes wants to dramatize the costs of immersion in subversive politics: trying to give people a deracinated sense of self is anotlier way of trying to cool radical ardor. More generally, liberals have insisted on individuahisin to puncture fantasies about serving the goals of listory. They want to inake it harder for groups to tell individuals stories about their ultimate and transcendent purposes-and tliey want to make it liarder for individuals to efface theinselves. Consider here Alexander Berkman's account of his decision to shoot Henry Clay Frick. Apparently without irony or detachment, Berkman writes, "Could anything be nobler than to die for a grand, a sublime Cause?" He hoped to have "neither personal interests nor desires above the necessities of the Cause," frankly einbracing the loss of personal identity the pose suggests: "My own individuality is entirely in the background; aye, I am not con-

13. Sparer, Fundamental Human Rights, Legal Entitlements, and the Social Struggle: A Friendly Critique of the Critical Legal Studies Movement, 36 STAN. L. REV. 509, 516-52 (1984).

14. Cf. A. MACINTYRE, AFTER VIRTUE 69 (2d ed. 1984) ("[T]here are no ["natural or human"] rights, and belief in them is at one with belief in witches and in unicorns"). 
scious of any personality in matters pertaining to the Cause."15 Adopting individualism, then, was an effort to slap people in the face, to make them capable of challenging group demands. In a locution fashionable right now among communitarians, individualism was empowering, not disempowering.

Similarly, talk about presocial individuals is strategic in the liberal tradition. Taken as a siniple descriptive claim, the notion that there could be persons outside society, or that we are born as fully constituted selves, is of course nonsensical. And the first articulate attack on the notion in modernity comes not from Marx, not from Burke or the French theocrats, but from the liberals of the Scottish Enlightenment. Describing individuals as presocial, imagining counterfactually what they miglit gain or lose by contracting to enter a political society, once again dramatizes the claim that persons are more than cannon fodder, more than eggs to be broken in the pursuit of omelettes. In a historical context where ordinary people liad long been exploited and taken for granted, this bold egalitariamisn is worth applauding, not condemning.

Nor need we read liberal claims about the primacy of self-interest as a simple psychological theory, one we can niock given our superior understanding of irrationality and ideology. Hobbes decries "the ordinary ignorance, stupidity and superstition of inankind;" 16 Locke insists on the place of unthinking habit and custom in liuman affairs; ${ }^{17}$ Adan1 Smitl tells a drily ironic story of how the nobility forfeited their power by failing to reahize their interests, by "selling their birthright . . . for trinkets and baubles, fitter to be the play-things of children than the serious pursuits of inen."18 Yet all these writers also make bland claims about the primacy of self-interest, thus posing exegetical riddles.

The solution again is to read claims about self-interest in their political context. Albert Hirschman has done a splendid job recovering part of the significance of the inove to interests, arguing that we find here an atteinpt to make political inoderation and deliberation possible in a way they are not when notions of passion reign supreme. ${ }^{19}$ But there is more to be said. Liberals have taken just as much delight as Marxists and Freudians in stripping away deceptive masks, in revealing loathsome underlying realities. Self-interest is a corrosive that strips away grand pretensions about the common good, or God's will, or the interests of the state. Belief in the primacy of self-interest sensitizes subjects and citizens

\footnotetext{
15. A. Berkman, Prison Memoirs of an ANarchist 7, 8, 9 (2d ed. 1920).

16. T. HoBBES, supra note 9 , at 474-75.

17. See, e.g., J. Locke, AN Essay Concerning human Understanding 356-57 (P. Nidditch ed. 1975) (4th ed. 1700).

18. 1 A. SMith, AN INQuiry into the Nature and Causes of the Wealth of Nations 421 (R. Campbell, A. Skinner \& W. Todd eds. 1979) (1776).

19. A.O. Hirschman, The PAssions AND the INTERests (1977).
} 
to the ever-present possibility that those in power will happily pursue their own interests, while telling much grander and nobler stories about what they're up to.

Sometimes the role played by egoism in liberal thought is apparently descriptive. Consider Adam Sumth's famous claim:

It is not from the benevolence of the butcher, the brewer, or the baker, that we expect our dinner, but from their regard to their own interest. We address ourselves, not to their humanity but to their self-love, and never talk to them of our own necessities but of their advantages. ${ }^{20}$

Some will want to say that soinehow Smith is celebrating meanspirited calculation agamst carefree largesse; but that readimg seems zany on its face. Smith, I would suggest, is making two poimts. First, he contimues playing a game near and dear to liberals: Aristotle-bashing. As a matter of fact, Smith holds, nothing like consensus on fundamental moral principles is required to lold society together, nor even a tensely knit family of disagreements about justice. Mere self-imterest may do the trick in soine social settings. Given the increasing historical difficulties in generating agreement im pluralistic societies, it was important to insist on this less strenuous account of social union. Second, Smith is making a point that's not purely descriptive after all, one we tend to miss if we don't understand the social referent. Talk of benevolence liere is manifestly not about 1960's communes, not about liazily extrapolating from fond meinories of summer camp to all of society. It's about the medieval ethic of service that surrounded relations of hierarchy and deference. Serfs and servants were held to be the friends of their masters, bound to them not by mere coercion but by affection and even love. Like Southern slaveholders, masters could feel betrayed when their "friends" fled, or stole from them, or turned out not to be brimming over with warmth after all. In rejecting benevolence, Smitlı forcefully remmds his reader that the world of market society is not the older world of intimiate deference. There arises the prescriptive kicker. If we appeal to the butcher's self-interest, we acknowledge his standing as a dignified agent. Figures as lowly as butchers, brewers, and bakers do not automatically junip to lick the boots of the wealthy and powerful in society, and no one even thinks of suggesting that they owe the latter service. And that change, surely, is a good thing. So Smitl's point is not a piece of philosophical psychology; it's an observation about what's acceptable in conversation and social life.

Liberals have sometimes endorsed egoism, thougl, in explicitly normative terıns, as a fine principle for governing one's own life. Why would they do this? Does it slow that liberals are meanspirited scoundrels with no appreciation for the "higher" things in human life? Not at

20. 1 A. SMITH, supra note 18 , at $26-27$. 
all. Once again all we need to understand the point is a bit of historical sensitivity, which immediately explains why selfishness would be worth endorsing. Consider the class of nonegoistic life plans. Some of those, of course, are warm and benevolent: Florence Nightingale was no egoist. But early modern Europe was not populated by Florence Nightingales. The syrupy descriptions of community that CLS writers routinely conjure up were not and could not have been on the minds of liberal writers. They had more pressing problems to tend to. The rehgious fanatics whose zeal propelled early modern Europe into civil war were not pursuing sober self-interest, to be sure. Neither were the nobles who led their retainers into battle in the pursuit of honor and glory. But it is absurd to conclude that either group was sweet, loving, and altruistic. There are many ways besides altruism to take an interest in others' interests. One can be cruel or malicious, too.

Finally, what reason have we to believe that these liberal feints and maneuvers somehow tell against the value of community? CLS writers, despite their occasional awareness of the problem, sometimes fall into a problem oddly common on the left, that of summoning up a golden age from which we have fallen. Morton Horwitz worries that "The recent revival of natural-rights individuahsm in legal and political theory ... is not only a dangerous symptom of the unravelling of all sense of commumity, but also a relapse into a predatory and vicious conception of politics."21 He worries too that the rule of law "prevents power's benevolent exercise."22 Unger manages to cast the transition to hberal modernity as "the disintegration of community."23 And Richard Abel, arguing that we should not compensate tort victims with monetary payments (lest we turn personal injuries into commodities and so alienate the victimsl), says that "We need, instead, to re-create a society that responds to misfortune with personal care. ..."24

Whatever poetic appeal it has, this picture is historically nothing but a pernicious fantasy. (Marx, who I daresay knew more history than do CLS authors, almost never succumbed to the temptation to cast modern society as a lamentable fall from feudal grace. His strategy was to applaud liberalism and capitahsm as unmistakable advances in human emancipation-and then to insist that future society will rescue humanity froin the enduring problems of hberal capitalism.) Individual rights did not frame a predatory and vicious pohitics; they represented attempts to tame the wild excesses of powerful nobles, capricious landlords, preda-

21. Horwitz, The History of the Public/Private Distinction, 130 U. PA. L. REv. 1423, 1427-28 (1982).

22. Horwitz, The Rule of Law: An Unqualified Human Good?, 86 YALE L.J. 561,566 (1977).

23. R. UNGER, LAW IN MODERN SOCIETY 62-63 (1976).

24. Abel, Torts, in THE Polrtics of LAW, supra note 3, at 185, 199. 
tory tax farmers, and the like. No one has ever had to fear that the rule of law prevents the benevolent exercise of power: State functionaries are hardly poised waiting to do us splendid good deeds that alas! they're forbidden by law froin doing. Indeed Locke is probably all too charitable, all too generous to his royalist opponents, in his glowing descriptions of the power of prerogative to break the law. The only coinmunity I can innagine that could have disintegrated was that among feudal lords and their serfs, and surely that had everything to do with exploitation and deference, nothing to do with egalitarian warmth and affection. Finally, there is an impressive tradition of inutual aid among the poor, but it sprang up as a half-effective response to remarkably callous political and legal policies. One thrown into a debtors' prison may discover that friends will try to scrape togetlier the funds to help out, but it hardly follows that we should reinstitute those prisons to recreate the opportunity to "respond to misfortune with personal care."

So CLS complamts about the liberal self rest, I suggest, on a striking failure to grasp the political probleins that made liberalisin attractive. Given the sheer ugliness of life at the beginnings of liberalisin, it's extraordinary to complam that liberals someliow hate communty. Nor is the point purely historical. Liberals today liave nothing against a plurality of communities-indeed they may riglitly urge that liberal toleration is the best safeguard of that plurality-but they may well worry that having ouly one community would rest on militant coercion. ${ }^{25}$ To take a convenient microexample, the notorious faculty imbroglios created by clashes between CLS figures and their opponents are a sign that law faculties are not one big happy community-but the only way to turn thein into one might be to drive out all the CLS types. So the ongoing pursuit of the CLS agenda in fact depends on law sclools' taking seriously the very liberal principles deplored by CLS. Shades of revolutionary defeatisin ....

\section{Reifying Social Relationships: The Case of Capitalism}

CLS writers insist on the radical contingency of social life. Though we inay assunie our roles and institutions represent some necessary order, they don't. They're socially constructed; they could be different; and they should be different. Generally indeed CLS writers want to suggest that social life is reinarkably loose-jointed, that it's simply a mistake, for example, to try to assign economics any explanatory priority in understanding law or other social realms. Marx becomes an attractive inodel insofar as lie trencliantly insisted that social relationships are not

25. See Herzog, Some Questions for Republicans, 14 POL. THEORY 473 (1986). 
natural; he becomes less persuasive in his economic-determinist mode, at least for most CLS authors.

There is a notable exception. If I read him correctly, Unger oddly hankers after the days when people believed that social hierarchy was natural, suggesting that the death of "natural order" makes social order more difficult ${ }^{26}$-as though life in feudal Europe was particularly orderly! This is reminiscent of Tocqueville's amazing claim that when feudalism was at its height, serfs were not degraded: "It is not exercise of power or habits of obedience which deprave men, but the exercise of a power which they consider illegitimate and obedience to a power which they think usurped and oppressive."27 Liberals, though, do not passively accept the plight of slaves, even if the slaves are happy. Insisting on the natural freedom and equality of men made social hierarchy radically contingent. One would expect, then, that liere CLS writers would sympathize with liberals.

Liberals, thougl1, elicit no such partial sympatlies; once again they are the fiends. Duncan Kennedy is typical: "The crucial lie of liberalism is that the mass of private law rules that define the capitalist system represent the normal, the free, the natural, or the boring, so that there is nothing to think or do about them."28 And indeed it is not difficult to quote liberals, eitlier hacks like Bastiat or profound ones like Smith, making such claims. Do all liberals think that market relationships are somehow natural or necessary?

No. In fact, some of the most spirited exercises in what CLS writers call trashing are undertaken by liberals against just such claims. Hume, for instance, bitterly mocks the claim that property riglits are the instantiation of any kind of natural order. Instead, lie urges, they are a social convention, no more and no less. To nail home the point he makes just the same theoretical move prized by generations of radical critics: $\mathrm{He}$ slifts to an external stance on the social institution of property.

I may lawfully nourish myself from this tree; but the fruit of another of the same species, ten paces off, it is criminal for me to touch. Had I worn this apparel an hour ago, I had merited the severest punishment; but a man, by pronouncing a few magical syllables, has now rendered it fit for my use and service. ${ }^{29}$

And of course the great liberal authors were historically adept. It would have surprised none of them to liear that society had been organized

26. R. UNGER, supra note 23 , at 127-33.

27. A. DE TocQueville, Democracy IN AMERICA 14 (J.P.Mayer ed, G. Lawrence trans. 1969) (1840).

28. Kennedy, First Year Law Teaching as Political Action, 1 LAw \& Soc. Probs. 53 (1980).

29. D. HUME, An Enquiry Concerning Morals, in ENQUIRIES CONCERNING HUMAN Understanding and Concerning the Principles of Morals 199 (P. Nidditch 3d rev, ed. 1978) (1777). 
along different lines, and might well in the future change again. Why then did liberals ever describe property rights or other social relationslips as natural or necessary?

In the case of property, the answer is clear: to try to keep the meddlesome hands of state officials out of the economy. The more one insists on the spontaneous order generated by market transactions, the more indefensible any kind of interference becoines. Nor is the drive to laissezfaire a sleazy atteinpt to protect the interests of capitahists. Smith, for instance, is keenly critical of those lie calls merchants and manufacturers. He opposes intervention because he thinks it will inake workers even worse off than they already are, and he embraces positive state action to help thein out. ${ }^{30}$ No part of this has any place in his celebrated stickfigure role in intellectual history as Capitalist Ideologue, but so much the worse for that reading.

In fact, as against popular mythology, liberal support for capitalism is contingent; the comrections between liberal politics and the econony are tenuous. Liberalisin was not born as an apology for a rising bourgeoisie-that view is absurdly teleological, since liberalism predates the bourgeoisie-but as a solution to religious civil war. Liberals care for the security and welfare of ordinary people, and championed capitalism as long as it seerned to them to be serving the interests of those people. The contingencies in liberal support of capitalism are theoretical and historical. Smith liad reasons, given his complex descriptive theory, to beheve that free inarkets leave people better off than does mercantilism; but he would happily agree that revising the theory could mean changing the policy outcomes. And selling one's labor on an open market needn't be decried as alienation when the alternative is onerous apprenticeships. As capitalism evolved, though, liberal affection for it faltered. It's not, as Austrian economists such as Hayek and von Mises have suggested, that those we now call liberals stole the label from bearers of the true Lockean faith. ${ }^{31}$ Some liberals articulated a case for the social welfare state as a new tool for serving the interests of ordinary people. Others, like John Stuart Mill, einbraced democratic socialism. ${ }^{32}$

Locke liimself is, I think, typically misunderstood on these issues. The relevant text, often singled out as the damning core of liberal theory,

30. I expand on this reading of Smith in D. HerzoG, WITHout Foundations: JUSTIFICATION IN POLITICAL THEORY 202-17 (1985).

31. F.A. HayeK, The ROAD to Serfdom 10-31 (1944); L. von Mises, The ANT1Capitalistic Mentality 90-105 (1972).

32. See, e.g., J.S. Mill, Principles of Political Economy, in 3 The Collected Works of JoHn STUART MILL (J. Robson ed. 1965) (1848) (especially Book IV, chapter 7, On the Probable Futurity of the Labouring Classes; Book V, chapter 11, Of the Grounds and Limits of the LaissezFaire or Non-Interference Principle; and the Chapters on Socialism, which Mill had not yet incorporated into Principles of Political EconOMY at the time of his death). 
is Chapter 5 of the Second Treatise, where Locke rhapsodically dwells on how people can pile up money without harming others. The reading I would recommend is connected to the poimt I pressed earlier about egoism. Consider the class of maximizing or acquisitive life plans, and leave open for the moment exactly what is being maximized or acquired. Religious fanatics sought to make the world as holy as they could; nobles sought to acquire as much honor and glory as they could. Both sorts of life plans had devastating consequences. Yet Locke didn't think one could stop people from being acquisitive. The trick, then, was to find some social space in which acquisition would not have sanguinary consequences. And, thought Locke-readers picturing children disappearing into the grinding gears of factory machinery should recall that he wrote in 1680-the economy provided just such a sphere. There is no doubt that Locke held the untrammeled pursuit of inoney in contempt; he could write, "Covetousness, and the Desire of having in our Possession, and under our Dominion, more than we have need of, being the Root of all Evil, should be early and carefully weeded out, and the contrary Quality of a Readiness to impart to others, implanted."33 Those devoted to wealth are wasting their time; they should be pursuing salvation. But unlike nobles and rehigious zealots, they don't bother other people. (Recall here too Candide's advice that we must cultivate our own gardens.)

Sociahists, then, misplace their attack when they indict liberalism for the ills of capitalism. Many liberals would agree with their critique of capitalism, and it is no accident that liberal versions of socialism are the only respectable ones around. Praise of market relationships as natural and self-ordering was again not some mystified reification of what is radically contingent, but a bid to halt the Colbertists of the world in their tracks, lest they further impoverish the already poor. (Feminists have a much better case in attacking liberal accounts of the family as natural, though here again there are liberals-Mill is the outstanding case-who would einphatically agree. Liberalism has been a theory about inen, not women; but there are liberal grounds for attacking that strand of the tradition.)

Another postscript: as far as I can tell, nothing of political note in the debate between CLS writers and liberals follows from accepting the claim that forms of life are socially constructed and not inandated by any kind of natural or transcendent necessity. It does not follow, for instance, that radical change may be achieved simply by persuading people of the social-construction thesis. Nor does it follow that everything must always be up for grabs. There are ghimpses in the CLS literature of

33. J. Locke, Some Thoughts Concerning Education, in THE EdUCATIONAL WRITINGS OF JoHN Locke 213-14 (J. Axtell ed. 1968) (1693). 
both these views, what we might call idealism and Bakuninism, but there are also critiques of them. So a charitable reading of their work requires that we not saddle them with such audacious and implausible views.

I recognize full well that this last move might be thought wrong on two grounds. First, CLS writers very much want to say audacious and implausible things, if only to loosen up our sense of what's possible in politics and scholarship. Second, CLS writers want to question the cogency and intelligibility of interpretation. I turn now to what is supposed to be the biggest liberal hoax of then all, the defense of the rule of law and legal interpretation.

\section{THE AUtonomy AND COHERENCE OF LAW}

In imposingly large letters, stretched around the walls of the main reading room of Harvard Law School's hbrary right under the ceiling, is a fatuous comment from Richard Hooker's Laws of Ecclesiastical Polity: "of lawe there can be no lesse acknowledged, then that her seate is the bosome of God . . .."34 Montesquieu offers similar raptures: "Law in general is human reason, inasmuch as it governs all the inhabitants of the earth: the political and civil laws of each nation ouglit to be only the particnlar cases in which liuman reason is apphed."35 And even Hume, for all his skeptical disdain for sucl lofty claims, loves law, calling it for instance "the source of all security and happiness." 36

This sort of talk invites some of the angriest CLS strictures, their attacks on formalism. Kennedy claims that: "Rights discourse is internally inconsistent, vacuous, or circular. Legal thought can generate equally plausible rights justifications for alinost any result."37 David Kairys asserts that "There is no legally required rule or result, and despite endless attempts by judges and legal scholars to find transcendent legal primciples, there simply are none." 38 Mark Kelman alludes to "the dissonant, fundamentally nondeductive nature of legal discourse."39 Unger insists "Tliere can be no coherent, adequate doctrine . . . of adjudication on liberal premises," and asks rlietorically, "is not the alleged autonomy of the legal order itself illusory?"40 Just as CLS writers some-

34. R. Hooker, 1 OF the Laws of Ecclesiastical Polity 142 (G. Edelen ed. 1977) (1597).

35. Montesquieu, The Spirit of THe Laws 6 (T. Nugent trans. 1949) (1748).

36. D. Hume, of the Rise and Progress of the Arts and Sciences, in EsSAYs, MORAL, Political, AND Literary 125 (Oxford Univ. Press ed. 1974) (1742).

37. Kennedy, Legal Education as Training for Hierarchy, in THE Polrtics of LAw, supra note 3 , at 40,48 .

38. Kairys, Freedom of Speech, in THE Polrtics of LAw, supra note 3, at 140, 161.

39. Kelman, Interpretive Construction in the Substantive Criminal Law, 33 STAN. L. REv. 591, 597 (1981).

40. R. UNGER, supra note 10 , at 83 ; R. UNGER, supra note 23 , at 55 . 
times fall into conjuring up the good old days, they sometimes fall here into conspiracy theories: Kelmedy claims that legal formalism is "designed to disguise," without giving us a clue as to who the designers might have been and how they could have deceived us so grossly. ${ }^{41}$

So we are invited, in the unkindest cut of all, to realize that the very idea of the rule of law is illusory. What should we make of these CLS claims? No doubt they're more plausible than the lofty claims of Hooker and the rest. We are simply too secular and too sociological to put much faith im God or reason when it comes to law, and ouly someone astonishmgly innocent of twentieth-century politics could suggest that the rule of law is the source of all security. But the CLS claims are instantly perplexing. One wants to know what the standards are-an important question in assessing any critique. Unger, for exainple, does not tell us what a "coherent, adequate doctrine" would look like; nor does he tell us what would constitute legal autonomy. This approach is sadly reininiscent of the more exotic claims Adorno pushed in his unintentionally droll indictments of mass culture, ${ }^{42}$ claims echoed in the CLS literature. When Gabel for instance holds that "people in fact are wandering around in a quasi-autistic stupor exchanging blank gazes with strangers on the street," ${ }^{23}$ we learn not that there is something wrong with us as we walk around, but that there is soinething drastically wrong with Gabel's criteria for autism.

The standards, perhaps, are those voiced by liberal theorists. If we're not going to acknowledge that law is simply reason applied to human affairs, then perhaps we've already surrendered whatever hope any formalist doctrine ever had. Predictably, I want once again to suggest that CLS writers misread hiberal doctrine by missing its political purposes. Since Blackstone has gotten plenty of airplay in this literature, I want to say soinething about Coke.

Coke's almost inystical reverence for the common law of England is

41. Kennedy, supra note 1 , at 219 . One could of course articulate a theory of hegemony without conspiratorial designers in the background, as indeed Kennedy sometimes tries to. See, e.g., id. at 210-11. That theory would do all the work CLS authors would want it to. So they should stop firting with conspiracy talk.

42. All too typical an example is T. Adorno, Minima Moralia: Reflections from DAMAGED LIFE 137 (E. Jephcott trans. 1978):

While the schools drill people in speech as in first-aid for road-accident victims and in glider-construction, the pupils become increasingly mutc. They can give lectures; every sentence qualifies them for the microphone, before which they are placed as spokesmen for the average; but their capacity for speaking to each other is stifled. It presupposes experience worth communicating, freedom of expression, and at once independence and relatedness. In an all-embracing system conversation becomes ventriloquism. Everyone is his own Charlie McCarthy: hence his popularity. Words in their entirety are coming to resemble the formulae which used to be reserved for greeting and leave-taking.

Feminists interested in Marxism might want to consult id. at 116-18, where Adorno's hostility to social differentiation leads him to express nostalgia for "the ancient unity of inn and brothel."

43. Gabel \& Kennedy, supra note 4 , at 36. 
well known: It would be easy enougli to pile up more majestic, formalist rlietoric from him on law, complete with loving references to the law of reason. But Coke was no fool and suffered no metaphysical delusions about his profession. He was maneuvering in a complex political battle against the Stuart monarclis, a battle in which liighflown rhetoric served lim as a potent weapon against the claims of absolute sovereign authority.

I cannot here say anything detailed about the political setting of seventeenth-century England: King Cliarles I was put to deatli in 1649, Puritan zealots ruled what was ostensibly a republican commonwealth until Cromwell took cliarge, monarchy was restored almost inagically in 1660, and the constitutional settlement of 1689 transformed Enghish politics. Throughout, a stream of events and arguments made it increasingly plausible to think that law and sovereignty were in fact diametrically opposed ideals. Hampden lost his case in 1638 when lie tried to persuade the judges in Exclequer Chamber that the king acted illegally in trying to raise ship money in peacetime. But Hampden's case made a decisive point anyway. It showed that one could coherently articulate a claim against the sovereign in a court of law. More generally, the pohtical debate inspired both sides to exaggerate their claims. The more Parliament's champions insisted on the power of Commons and of law, the more the Stuart monarchs imsisted they were absolute sovereigns, the inore they insisted they were absolute, the more Parliament's clrampions insisted on Commons and law. (This dynarmic, common enougli, should be recalled when democratic theorists are arguing that debate leads to reasonable compromise.) By 1651 (after a bloody civil war), Hobbes had gotten the point, and lis defense of sovereignty included a spirited attack on Aristotelian foolery about the rule of law. ${ }^{44}$

Coke, I think, had an mcisive understanding of the possibilities here early on. He wasn't, despite the suggestions of Whig historians, a zealot devoted to an ascendant House of Commons, but lie was a cliampion of what we might well call the autonomy of law. Coke pressed the claims of judicial independence well before others were willing to join him, and an infuriated James finally dismissed him froin the King's Bench in 1616. A page in his Reports on a debate he had with James in 1607 makes the issues clear:

Then the King said, that he thought the law was founded upon reason, and that he and others had reason, as well as the judges. To which it was answered by me, that true it was that God had endowed his Majesty with excellent science and great endowments of nature, but his Majesty was not learned in the laws of his realm of England, and causes which concern the life, or inheritance, or goods, or fortunes of his subjects are

44. T. HoBBES, supra note 9 , at 699. 
not to be decided by natural reason but by the artificial reason and judgement of law, which law is an act which requires long study and experience before that a man can attain to the cognisance of it, and that the law was the golden mete-wand and measure to try the causes of the subjects, and which protected his Majesty in safety and peace. With which the King was greatly offended. ... 45

The claims of expertise, the dehberately exalted portrayal of law as a golden wand, are transparent in this context. They mean simply that the king shouldn't interfere in legal matters or fancy himself to be the law.

Liberal affection for law and liberal claims about the majesty and autonomy of law generally work the same way. The relevant standards for comparison are provided by the actual historical alternatives. Disputes can be settled in courts, with settled legal doctrine and lawyers representing the parties. They can also be settled, and were settled, by drunken lords, or captious priests, or bloody self-help. No doubt judges can be drunken, lawyers captious, and enforcement bloody; but liberals saluted the emergence of an independent legal realm as an improvement in popular security and welfare. Recalling Star Chamber and High Commission, recalling the royal dispensing power that set free offensive nobles, what one historian calls fur-collar criminals, ${ }^{46}$ at a wave of the King's hand, recalling arbitrary proclamations here today and gone tomorrow, we should be hard pressed to think that liberals were mistaken in placing some confidence in professional lawyers. It's easier to live under the common law than it is to live under Caligula.

Liberals, I would also suggest, were not taken in by their own lofty rhetoric: Bentham's nasty attack on Blackstone is notorious. Again, claims for the autonomy and coherence of law are political through and through. They are bids to take legal decisionmaking out of the hands of those with explicitly pohtical interests who exercised their power arbitrarily, to make it more regular, more predictable, and more accountable. That was a real change: Law used to be transparently political. The history of early modern Europe is full of incidents that make it obvious why liberals pressed for a separation of law and politics. One among many will have to suffice here.

In December 1613, James I, worried by the lack of money that plagued the Stuart monarchs, pressed ahead with a scheme to establish a plantation system in Ireland. Doing so required extensive changes in Irish land tenure, but James wasn't fazed. A jury was summoned at Wexford and instructed to find the King's title legal. James had good

45. E. COKE, 6 The RePorts OF Sir EDWARd COKE 282 (J. Thomas \& J. Fraser eds. 1826), reprinted in THE STUART CONSTITUTION 181 (J. Kenyon ed. 1980).

46. Hanawait, Fur-Collar Crime: The Pattern of Crime Among the Fourteenth Century English Nobility, 8 J. Soc. HisT. 1, 1-17 (1975). 
reason to be confident in the outcome: the jury had been packed with members who had a financial stake in the proposed plantations. But the jury didn't consult their economic self-imterest. They declared against the crown. This failure to cooperate got them summoned before Exchequer, where the genuinely recalcitrant jurors were sentenced to prison, censured, and probably fined. The others, their numbers replenished by additional jurors with a financial interest in the plantation, dutifully found for the King. ${ }^{47}$

Demanding the separation of law and pohitics in this context ineant demanding an end to such abuses of the law. It did not mean imagining some bizarre world in which the practice of law would inake no pohitical difference. There is then no reason to be scandalized by the "revelation" that judicial decisionmaking is still pohitical. Legal cases do raise pohtical issues. But the political issues are typically remote from the world of daily politics, in ways that make judicial rulings more than declarations of the judges' first-order partisan commitments or "subjective preferences." Bitter gerrymandering disputes between Republicans and Democrats may force a court to stake out a view on the logic of representation in a liberal democracy. An angry secondary boycott in the meatpacking industry may force a court to articulate a view about the extension of agency and responsibility in institutional settings. And so on. There is no reason to underplay the sorts of transformation that ordmary political disputes undergo when they enter courtrooms. Liberals-and others fond of the rule of law-need not deny tliat political considerations enter. They need only say that what happens im court is better than the available alteruatives.

It really is true then that judges can rule against their own partisan views or economic interests, and when they do so they are not necessarily mystified, the victims of their own formatist rhetoric. On the Supreme Court, Justice Holmes insisted that "The Fourteenth Amendment does not enact Mr. Herbert Spencer's Social Statics" in arguing that New York could regulate the number of hours per week bakers could be employed; off the bencli lie mocked imterventionism, saying of monopolies for instance that "objections to unlimited private ownership are sentimental or political, not economic." 48 Holmes, of all people, was surely aware that deciding the constitutionality of New York's law presented political issues. But he was also capable of divorcing his own predilections about the merits of the regulation from the relevant legal issues.

Mafficking CLS scholars might jump on this "concession" to insist

47. 8 S. GARDINER, History OF ENGLAND fROM tHe ACCESSION OF JAMES I to THE OUTBREAK OF THE CIVIL WAR 1603-1642, 1-4 (1965).

48. Lochner v. New York, 198 U.S. 45, 75 (1905); see also O.W. HoLmES, Economic Elements, in Collected Legal Papers 280 (1920). 
that the jig is up. All the differences, they might say, are illusory. The realists did not press the critique far enough, but again legal doctrine can accommodate almost any result. How might this view be defended? Sometimes there is an embarrassingly crude shide, from "there are arguments on both sides of the issue" to "one can plausibly rule either way." But of course it's possible that the arguments on one side are much better. The CLS critique of law here apphies just as (im)plausibly to science, where there may be evidence for and agamst some hypothesis. Does anyone want to say that in science we could justify any view?

Sometimes, though, there's a more nihilistic move. Suppose I am reading Mark Tushnet's article on constitutional interpretation, Following the Rules Laid Down, and trying to figure out what it says. ${ }^{49}$ The main outlines seem clear enough. Liberal jurisprudence is-surpriselcontradictory. Constitutional theory is needed to inaintain order while diffusing sovereignty in a world of monadic individuals with competing purposes. Rules of interpretation are needed to constrain the power of judges, but these rules can only acquire content by reference to organic social structures and wide social consensus, both of which undermine the "individualist premises" of hiberal legal thought. ${ }^{50}$ This arguinent is just wrong, even if we grant its caricature of hiberal individualisin. Tushnet conflates (1) people agreeing on the ineaning of words, rituals, symbols, and the rest with (2) people sharing purposes. But the two are independent. Indeed, only people who agree completely on what things mean can clearly grasp and so fully loathe each other's purposes.

Tushnet, though, flirts with a radical Wittgensteinian skepticisin about the very possibility of rules constraining our practices, noting that any series of numbers can be continued in any way, and we can always find a mathematical rule that correctly describes the continuation. If that is so, he suggests-here's a leap an intellectual daredevil should hesitate at, but it doesn't even make Tushnet pause-“"that in any interesting case any reasonably skilled lawyer can reach whatever result he or she wants." 51 Presto! everything is up for grabs. Or so Tushnet seems to suggest.

Sanford Levinson has cautioned us not to fly off the handle with accusations of nihilism at such claims: "As I understand him, Tushnet does not argue that every single legal term is up for grabs at every moment, only that every term is potentially up for grabs should a clever

49. Tushnet, Following the Rules Laid Down: A Critique of Interpretivism and Neutral Principles, 96 HARV. L. REV. 781 (1983).

50. Id. at 783-85.

51. Id. at 819 . 
lawyer, backed by a powerful client, find it useful in a given situation."52 Perhaps Levinson's caution is right, though it's not clear then what all the fuss is about. But perhaps Levinson blunts the deliberately bold edge of Tushnet's attack. It is not all that consoling to think that things are up for grabs only when someone wants them to be. I think Tushnet does summon up a freewheeling skepticism, a view in which any text can mean anything we want it to. Even if I'm wrong about that, though, it's worth noting briefly some of the obvious conundrums facing any radical skepticism about interpretation, just in case anyone is tempted by such a view.

I have a distressingly large hibrary, one which keeps growing. I lug books from my apartment to my office, from one library to another, from New York to Michigan. I pile thein up and occasionally face the incredibly dreary task of loading them into boxes. Why do I bother? Why don't I just have one text, say a large piece of paper with the tantalizing word "TEXT" inscribed in the middle in Gothic lettering? I could then interpret it any way I wanted: I could read Henry James into it, or out of it, or Joyce, or Simmel, or . . . A And why does Tushnet publish so much? Could he hold the skeptical view about his own work? Would he never complam that he had been misread? Suppose I read Tushnet's article-or the Constitution - as the story of a small boy growing up in Kansas during the Great Depression. (Suppose I read all texts that way.) Is that just a view the commumity is not likely to endorse, or is it wrong? ${ }^{53}$

The occasional radical skepticism of CLS writers about legal interpretation is once again, I think, a case of overly demanding standards. CLS writers pose a stark binary choice: either the law tells passive judges what to do, either rules times facts equals decisions, or it is all up for grabs and anything goes. It would be profitable here for defenders of legal interpretation to explore middle grounds, to articulate positions that differ from both. And it would be profitable for CLS skeptics to do more than gesture in the direction of general skeptical arguments. One would very much like to see, for instance, full mock opinions supporting the legality of what would conventionally pass for utterly unjustifiable murder, or restatements of tort law that don't even refer to injury or causality, or that permit or enjoin armbreaking for fun and profit. Until CLS writers provide such exercises, we can I think shelve their skeptical suggestions with Descartes and Berkeley.

52. Levinson, What Do Lawyers Know (And What Do They Do with Their Knowledge)? Comments on Schauer and Moore, 58 S. CAL. L. REv. 441, 451 (1985) (emphasis in original).

53. This point is wholly compatible with the account of interpretation furnished by Stanley Fish, which centers on the role of interpretive communities. S. FisH, Is There a TeXT IN THIS CLASs? (1980). I mean to contrast the brute fact of the community's verdict with what they should say, given their own views and practices. 


\section{CODA}

The reader will have noticed (if the reader is committed to thinking my text has a meaning) that I have placed a reading of liberalism at the center of much CLS work, and then argued that that reading is a mess. Liberals, I have argued, did not advance a set of hopelessly naive claims about subjectivity, individualism, the naturalness of social relationships, and the formalism of law. Instead they brandished such claims as political weapons. And their goals were admirable: they sought to put an end to religious civil war, to alert individuals to the potentially oppressive claims of groups and leaders, to stop market meddling that impoverished already poor workers, and to ehminate capricious sovereign meddling im legal affairs. But I don't intend to summon up an apocalyptic dismissal of CLS, since part of what they're up to seems to me to be enormously valuable.

In 1930, Karl Llewellyn made a bid "to force attention to the relations and interactions of law and the rest of society." engender standard law and society materials, and legal behaviorism, which applied the quantitative methods of mainstream social science to law. The result, I daresay, has done neither social science nor law any credit.

Llewellyn's bid is still open, as far as I can tell. We need more legal studies that aren't narrowly internalist renditions of doctrine, but that don't try to reduce doctrime to an epiphenomenal reflex of economics, or anything else. We need inore legal studies that aren't obsessed with the drama of appellate review. Instead we need richly theoretical ways to explore the interaction of law and other social mstitutions. Some CLS writers are on their way to domg that. My advice, not that anyone's beatimg down my door for it, would be that they drop their mechanical polemic agamst hiberalism, and that they don't insist ahead of time that the analysis be radical. The analysis may well be radical often enough to satisfy our most critical critics. Be that as it may, legal scholarship that drew on the likes of Weber, Marx, and Simmel to place law in broader social contexts would be a terrific contribution.

54. Llewellyn, A Realistic Jurisprudence-The Next Step, 30 CoLUM. L. REv. 431, 443 (1930). 


\section{California Law Review}

\begin{tabular}{lll}
\hline \hline Vol. 75 & MARCH 1987 & No. 2 \\
\hline \hline
\end{tabular}

Copyright $(\mathcal{1} 1987$ by California Law Review, Inc.

\section{BOARD OF EDITORS}

1986-87

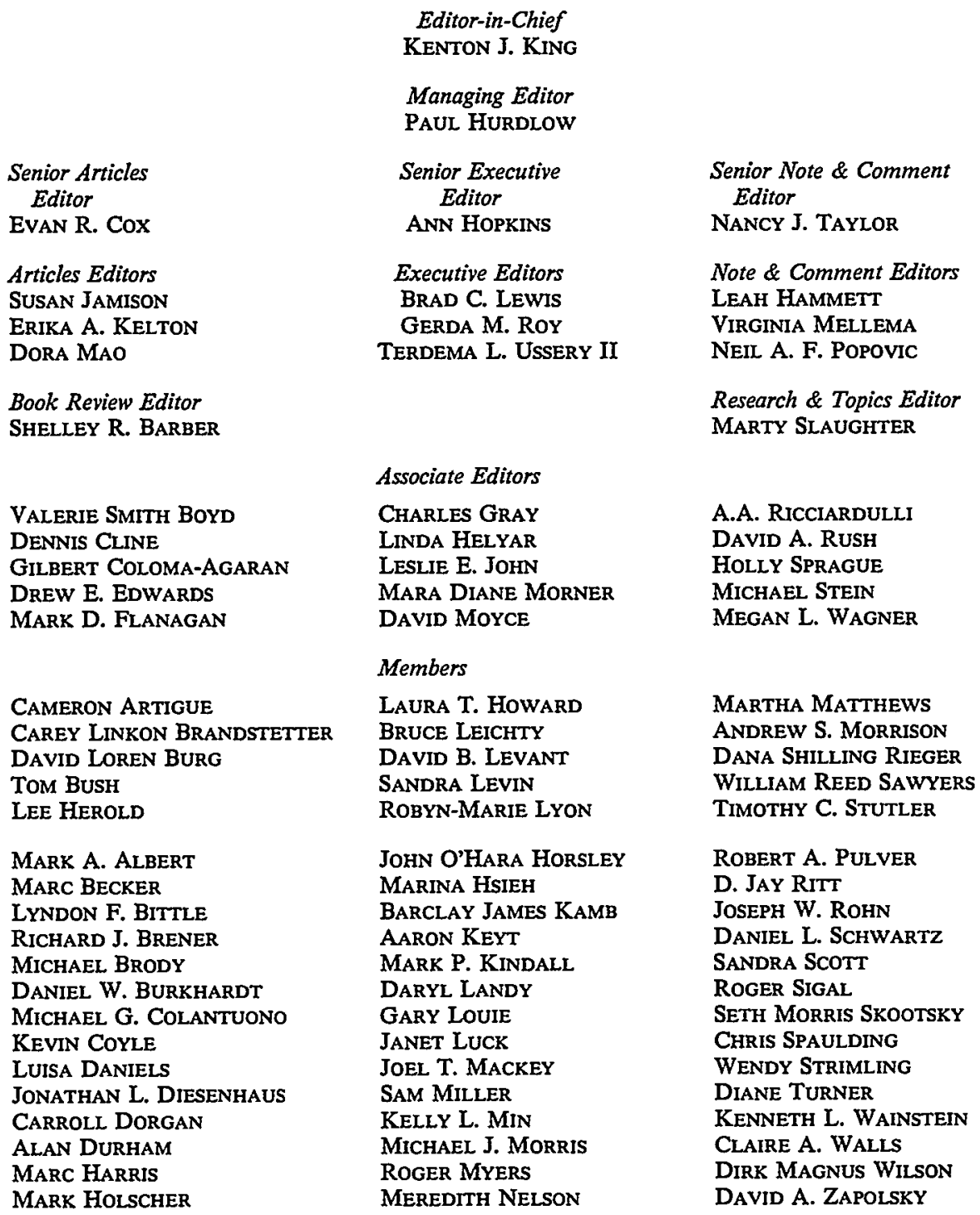


